\title{
ODPOWIEDŹ NA RECENZJĘ KSIĄŻKI POLSKA KRYTYKA JAZZOWA XX WIEKU. ZAGADNIENIA I POSTAWY*
}

$\mathrm{D}$ ziękując recenzentce, Profesor Magdalenie Dziadek, za komentarze i uwagi, chciałbym się do nich odnieść i przedstawić kilka uściśleń i wyjaśnień.

Pierwsza wątpliwość recenzentki tyczy samego pojęcia „krytyka jazzowa”. Krytykę muzyczną najogólniej rozumiem jako (publiczną, kompetentną i periodyczna) praktykę piśmienniczą, której przedmiotem jest dziedzina muzyki (analogicznie do krytyki teatralnej czy filmowej). W ramach takiej praktyki pojawiają się (mniej lub bardziej wyraziście osadzone w życiu muzycznym) rodzaje czy nurty krytycznomuzyczne odnoszone do węższych kategorii dziedziny muzyki jako swych przedmiotów: np. gatunku (krytyka operowa) czy rodzaju muzyki (krytyka jazzowa). Pewnym problemem jest tu kwestia terminologiczna: językowa tożsamość określenia „krytyka muzyczna” jako praktyki umocowanej historycznie oraz jako kategorii odnoszonej do dziedziny muzyki i rozpatrywanej w trybie systematycznym. W tym ostatnim ujęciu w tle pozostaje fakt historycznego ukształtowania się krytyki muzycznej na gruncie muzyki „profesjonalnej” i tym samym uchylone zostaje przekonanie, iż czerpanie stąd elementów praktyki krytycznomuzycznej przez powstałe później inne rodzaje krytyki przesądza o ich (immanentnej) alternatywności. Recenzentka dobrze rozpoznaje punkt widzenia autora, pisząc, iż „autorowi nie chodzi o zaakcentowanie specyfiki krytyki jazzowej ze względu na socjologiczne usytuowanie jako reprezentującej kulturę alternatywną" (s. I76). Muzyka jazzowa a za nią jazzowa krytyka w swej istocie programowo nie mają wymiaru alternatywnego:

* Zob.: Muzyka 66 (2021) nr 2, s. 177-181. lokują się po tej samej - „profesjonalnej” i „wysokiej” stronie (można by nawet zaryzykować tezę, iż swoje krytycznomuzyczne rozwinięcia mają te rodzaje muzyki, które aspirują do „artystyczności”).

Przyjmując systematyczny porządek rozumienia krytyki muzycznej, krytyka jazzowa w pierwszym rzędzie konstytuuje się przez swój przedmiot: jazz stanowi tu więc swoiste „zawężenie” w stosunku do całej dziedziny muzyki. Pozostanie przy tym stwierdzeniu mogłoby być wystarczające, gdyby jazz był rodzajem muzyki odrębnym tylko pod względem formalno-stylistycznym. Tymczasem inna jest ontologia i kondycja jazzu, a swoisty sposób jego istnienia niesie szczególnego typu implikacje właśnie w perspektywie krytycznomuzycznej. Odniesienie się do całości ontologicznej i epistemologicznej natury dzieła muzyki jazzowej wymagałoby odrębnego studium, w pracy zagadnienia te zostały jedynie zasygnalizowane, ograniczając się do związków z problematyką krytycznomuzyczną.

Przywołane przez recenzentkę zróżnicowanie przedmiotu (historycznej, tradycyjnej) krytyki muzycznej i krytyki jazzowej oparte na tym, iż ta pierwsza odnosi się do dzieła jako bytu „niezmiennego”, zaś w drugiej do (pozbawionego „dzieła-schematu”) dzieła „immanentnie otwartego”, jest zbytnim uproszczeniem. Tradycyjna krytyka może komentować dzieło-schemat, komentując zaś (częściej) zróżnicowane i zmienne wykonania tego dzieła (co tworzy „otwarty” i nieskończony pęk relacji: dzieło-schemat a jego wykonania), każdorazowo konfrontuje je z dziełem-schematem. W jazzie dzieło w swej schematycznej postaci (przyjmijmy: jako standard) ma inny status niż wspomniane, dookreślone przez 
kompozytora, dzieło-schemat i - pozostając z natury otwarte - w akcie danego wykonania staje się dziełem jednorazowym, skończonym i w tym sensie „zamkniętym”. Jako takie staje się przedmiotem jazzowej krytyki, bowiem - jak twierdzę - „w przypadku dzieła muzyki jazzowej, z uwagi na jego immanentną otwartość [...], przedmiotem recepcji każdorazowo pozostaje dzieło w swej jednostkowej, niepowtarzalnej postaci” (s. 6-7). Zatem - wbrew temu, co twierdzi recenzentka - dzieło jazzowe da się uchwycić w swej jednorazowości, więcej: to właśnie owa „jednorazowość” (koncertowa realizacja „tu i teraz” bądź rejestracja fonograficzna) jest przedmiotem uwagi krytyki jazzowej. Nie istnieje więc polaryzacja krytyki oparta na kryterium „niezmienności”/,otwartości” dzieła. Przyjęcie zasadności takiej polaryzacji prowadzi do jałowej w istocie kwestii „różnicy tożsamości muzyki tradycyjnej i jazzowej” rozpatrywanej z perspektywy (odmiennego) charakteru ich nośników (s. I77). Przedmiotem tradycyjnej krytyki muzycznej i krytyki jazzowej pozostaje w pierwszym rzędzie dzieło jako fenomen brzmiący (jako takie może ono też dopiero zyskać sens i wymiar kulturowy). Nośnik, rozumiany jako prosta forma utrwalenia muzyki (papier, płyta), ale też fakt braku takiego nośnika, ma tu znaczenie wtórne. Dla krytycznomuzycznej praktyki istotna jest natomiast kwestia bardziej subtelna: natura i sposób istnienia jej przedmiotu: czy - upraszczając - jest to dzieło-schemat lub pozostające w ścisłej odeń zależności jego liczne wykonania - w krytyce tradycyjnej, czy jednorazowe dzieła-wykonania - w krytyce jazzowej (dzieło i jego wykonanie są tu tożsame, co w perspektywie krytycznej uchyla tradycyjną relację dzieła i jego wykonania). Sytuacje te pozostają zróżnicowane pod względem szeregu istotnych dla perspektywy krytycznej uwarunkowań i stąd to one w zasadniczy sposób polaryzują praktykę krytycznomuzyczną. W krytyce jazzowej w grę wchodzą tu m.in. kategorie: indywidualnej kreatywności twórcy, interakcji między muzykami, oddziaływania odbiorców, ekspresji wykonawczej itd., co generuje swoistą perspektywę oglądu i odmienności przyjmowanych kryteriów. Kwestia statusu dzieła jazzowego w perspektywie jego implikacji dla praktyki krytycznomuzycznej - poza jedynie wzmiankowaniem we Wstępie, do którego odwołuje się recenzentka - została w pracy podjęta szerzej (choć ze świadomością niepełności) w rozdz. I „Jazz jako przedmiot krytyki muzycznej” (s. I9-48).

Nie wyodrębniam - jak twierdzi recenzentka - krytyki jazzowej jako kategorii „piśmiennictwa podlegającego presji ideologii, polityki, obyczaju”. Jako takich, uwarunkowań tego rodzaju (w istocie w jakimś stopniu zawsze obecnych) nie postrzegam jako delimitujących dla krytyki jazzowej, a jedynie jako także (jak w innych formach aktywności krytycznomuzycznej) będących jej udziałem, „wchodzących w grę” (s. 7). Uwarunkowania te nie definiują zatem krytyki jazzowej, zróżnicowane natomiast pozostają sposób, zakres i konsekwencje ich oddziaływania na praktykę krytyczną, co wpisuje się w szersze ujęcie: „respektując ogólne kontury krytyki powzięte z krytyki muzycznej, pozostaje uwzględnienie ich swoistości w odniesieniu do krytyki jazzowej” (s. 7). Taka sytuacja prowadzi do kształtowania się względnie autonomicznej pozycji krytyki jazzowej.

Za „słaby punkt” recenzentka uznaje wyróżnienie w dziejach polskiej krytyki jazzowej „fazy prekrytycznej” (usterka w odnośnym zdaniu nie powoduje jego nieczytelności, gdyż wyznaczone są ramy „okresu prekrytycznego”, ale poprawniej fragment ten powinien brzmieć: „okres wyznaczony przez początek lat dwudziestych i rok I956"). Przyjęcie takiego rozwiązania opiera się na (przywołanych wyżej) kryteriach formalnych konstytuujących i definiujących krytykę muzyczną (i jazzowa), których spełnienia w owym okresie nie znajdujemy. Za- 
razem okres ten był istotny jako właśnie czas „prekrytycznego” dokumentowania początków polskiej recepcji jazzu i wpisywania tematyki jazzowej do praktyki krytycznomuzycznej (w ramach krytyki muzycznej).

Zagadnienie, jak elementy jazzowe objawiały się w muzyce tanecznej (w tym kwestia, czy w Polsce przed rokiem 1939 grano jazz) oraz problem, o czym myślano i co miano na myśli, używając wówczas określenia „jazz”, pozostają złożone i nie w pełni rozstrzygnięte. W roku 1956 istniał już natomiast zarówno wiarygodny stylistycznie przedmiot krytyki jazzowej, jak i jej formalnie domknięty kształt (miesięcznik Jazz), co pozwoliło wyznaczyć tu cezurę periodyzacyjną (por. rozdz. V „Krytyka jazzowa: inicjacja i rozwój (1956-1965)”. Daje to odpowiedź na pytanie recenzentki: „Czy zatem historię polskiej krytyki jazzowej należy rozpoczynać dopiero od 1956 r.?”.

Kolejne wątpliwości recenzentki budzi twierdzenie, iż w okresie prekrytycznym „opinie o jazzie wyprzedzały w istocie jego rzeczywistą obecność w polskim życiu muzycznym" (s. 6). Z tej konstatacji rejestrującej pewną właściwość omawianej sytuacji recenzentka wyprowadza nieuprawniony wniosek, jakobym „redukował krytykę do jej form będących reakcjami na rzeczywiste (dziejące się tu i teraz) wydarzenia i tworzył odrębną perspektywę dla refleksji krytycznomuzycznej o charakterze lekturowym" (s. 178). Gdyby tak było, nie przywoływałbym przeważającej części opinii $\mathrm{z}$ owego prekrytycznego okresu jako opinii jedynie lekturowych, zatem rzekomo wymagających redukcji. Obecność czy nieobecność jazzu w danej kulturze $\mathrm{w}$ żadnym razie nie może implikować w jego komentowaniu oddalenia korzystania z takich źródeł, stąd uwzględniam wszelkie komentarze, co dwukrotnie potwierdza sama recenzentka, pisząc, że „obie te postacie bardzo często współistnieją ze sobą, [co] zresztą pokazuje rozdział trzeci książki, będący sprawozdaniem $\mathrm{z}$ rozwoju polskiej refleksji «prekry- tycznej» o jazzie" (s. I78) i odnosząc się do „przekazów z książek i prasy zagranicznej, które silnie inspirowały krytyków, co doskonale zresztą widzimy na przykładzie materiałów zgromadzonych przez Ciesielskiego" (s. I8o). Dodać tu należy, iż jazz był wówczas zjawiskiem w swej specyficznej kondycji na tyle nieznanym, że jego rozpoznawanie miało charakter niezmiernie złożony, bynajmniej nie polaryzujący się (jeśli w ogóle) według kryterium bezpośredniego doświadczenia i lekturowości. Po obu stronach znajdowały się opinie kompetentne, jak i całkowicie dyletanckie.

Twierdzenie, iż jazzowa krytyka była promotorem jazzu jako „zjawiska nowego i obcego kulturowo" (s. II) wynikało z samego i samoistnego faktu powstania tego rodzaju krytyki oraz charakteru jej aktywności dążącej do „objaśnienia” i wpisania jazzu w polskie życie muzyczne, nie zaś z jakiejś powinności promocji wszelkich „nowości” (niezasadne jest więc w tym kontekście przywołanie sytuacji innej „nowości” - „zachodniej awangardy”). Przy czym promotorski wymiar komentowania jazzu (bo wówczas jeszcze nie „krytyki jazzowej”) nie dotyczył jedynie „katakumbowego” okresu jazzu, a stanowił jej stały rys.

W tym kontekście stawia recenzentka kwestię możliwego istnienia „piszących o jazzie krytyków”, którzy, „będąc członkami jakiejś muzycznej diaspory, równocześnie występują przeciw jej dążeniom" (s. I78). Krytyka jazzowa (jak każda) obejmuje mnogość autorów i ich zróżnicowanych wypowiedzi i stanowisk. Stawiać tu można szereg zasadniczych kwestii: Czy wszyscy krytycy jazzowi byli członkami owej (jakkolwiek rozumianej) „muzycznej diaspory”? Czy każdy autor piszący o jazzie już z tej racji jest krytykiem jazzowym (należy do „muzycznej diaspory")? Czy z definicji jest on (powinien być) „projazzowy”? A jeśli jest „przeciw”, czy przestaje być krytykiem jazzowym? Czy - niezależnie od charakteru wyrażanych opinii - pozostaje on jednak 
w obszarze krytyki jazzowej? itd. Poszerzając perspektywę, można wskazać sytuacje (np. w krajach byłego bloku wschodniego), gdy krytyka jazzowa nie powstaje, bądź gdy sposób komentowania jazzu praktycznie podważa jego swobodne funkcjonowanie w danej kulturze. Na takim tle inaczej jawi się istnienie i projazzowa orientacja polskiej krytyki jazzowej.

Przywołany przez recenzentkę brak ostatecznego rozstrzygnięcia kwestii kompozycja a improwizacja wynika $z$ dwóch powodów: z jej wykraczania poza zakres pracy, a w większej części z możliwości spojrzenia nań przez autora jednocześnie $\mathrm{z}$ pozycji badacza, muzyka jazzowego i krytyka muzycznego, co daje wszak szeroką perspektywę widzenia, ale zarazem uwrażliwia na zbyt łatwe dokonywanie tu jednoznacznych ustaleń.

Wątpliwości recenzentki budzi też konstatacja: „istnienie danego rodzaju krytyki $\mathrm{w}$ pierwszym rzędzie zależy od istnienia $\mathrm{w}$ danej kulturze przedmiotu tejże krytyki”. Twierdzi dalej, iż „trudno przecież przypuścić, by ktoś chciał stale pisać o tym, czego nie ma” (s. I8o). Sytuacja taka - jako forma „przejściowa” między całkowitym brakiem krytycznomuzycznego komentowania danego przedmiotu a odnoszeniem się doń na gruncie właściwego dla owego przedmiotu rodzaju krytyki - miała jednak w znacznym stopniu miejsce w okresie (stąd określenie) „prekrytycznym" polskiej krytyki jazzowej, gdy na gruncie krytyki muzycznej pisano o jazzie wobec braku w polskiej rzeczywistości muzycznej jego stylistycznie wiarygodnej postaci.

Komentowanie jazzu opierało się na ogół nie na jego bezpośrednim doświadczeniu wynikającym z uczestnictwa w pol- skim życiu muzycznym, a było rezultatem doświadczeń lekturowych, fonograficznych bądź zagranicznych prezentacji jazzu (por. m.in. omówione w pracy relacje Karola Szymanowskiego). Ta druga perspektywa - zdaniem recenzentki - „potrafi być tak samo twórcza jak "krytyka właściwa»" (s. I78). Podzielając ten pogląd, stwierdzić jednakże trzeba, iż sytuacja taka nie tworzy jeszcze i nie pozwala mówić o krytyce jazzowej jako wyodrębnionym rodzaju krytyki muzycznej.

Budzące zastrzeżenia recenzentki powoływanie się na Nowy Kurier Warszawski byłoby zasadne, gdyby stanowiło zasadniczą podstawę źródłową. Tu ma ono z jednej strony charakter epizodyczny i faktograficzny (anonse, sprawozdania), z drugiej - wynika z chęci ukazania tych nielicznych świadectw obecności tematyki jazzowej nawet w prasie gadzinowej jako dokumentu swego czasu. Zarazem spojrzenie na funkcjonowanie jazzu w l. I939-45 musi uwzględniać szereg uwarunkowań, stąd przytaczane źródła lokować trzeba zawsze w (zarysowanej w pracy, s. I44-I46) złożonej i dwuznacznej sytuacji jazzu w realiach okupacyjnych.

W recenzji zawierającej szereg uwag krytycznych, stwierdzenie recenzentki, iż „książka jest napisana przejrzyście, a jej ton jest tak spokojny i obiektywny, jakby mowa była o muzyce dawnej" (s. I8I), traktuję jako wskazanie na zaletę pracy, wskazanie tym cenniejsze, że - jeśli interpretacja autora jest właściwa - uchyla ono potencjalnie tendencyjne podejście do przedmiotu badań zaangażowanego w sprawy jazzowe autora.

Rafat Ciesielski 


\section{JÓZEF ELSNER}

UTWORY FORTEPIANOWE PIANO WORKS

○

PIEŚNI

SONGS
MSZE OP. 26, 35, 42, 62, 75

MASSES OPP. 26, 35, 42, 62, 75

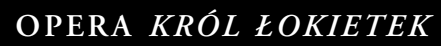

CZYLI WIŚLICZANKI

\section{Monumenta Musicae in Polonia}

REDAKTOR $・$ EDITOR

Barbara Przybyszewska-Jarmińska

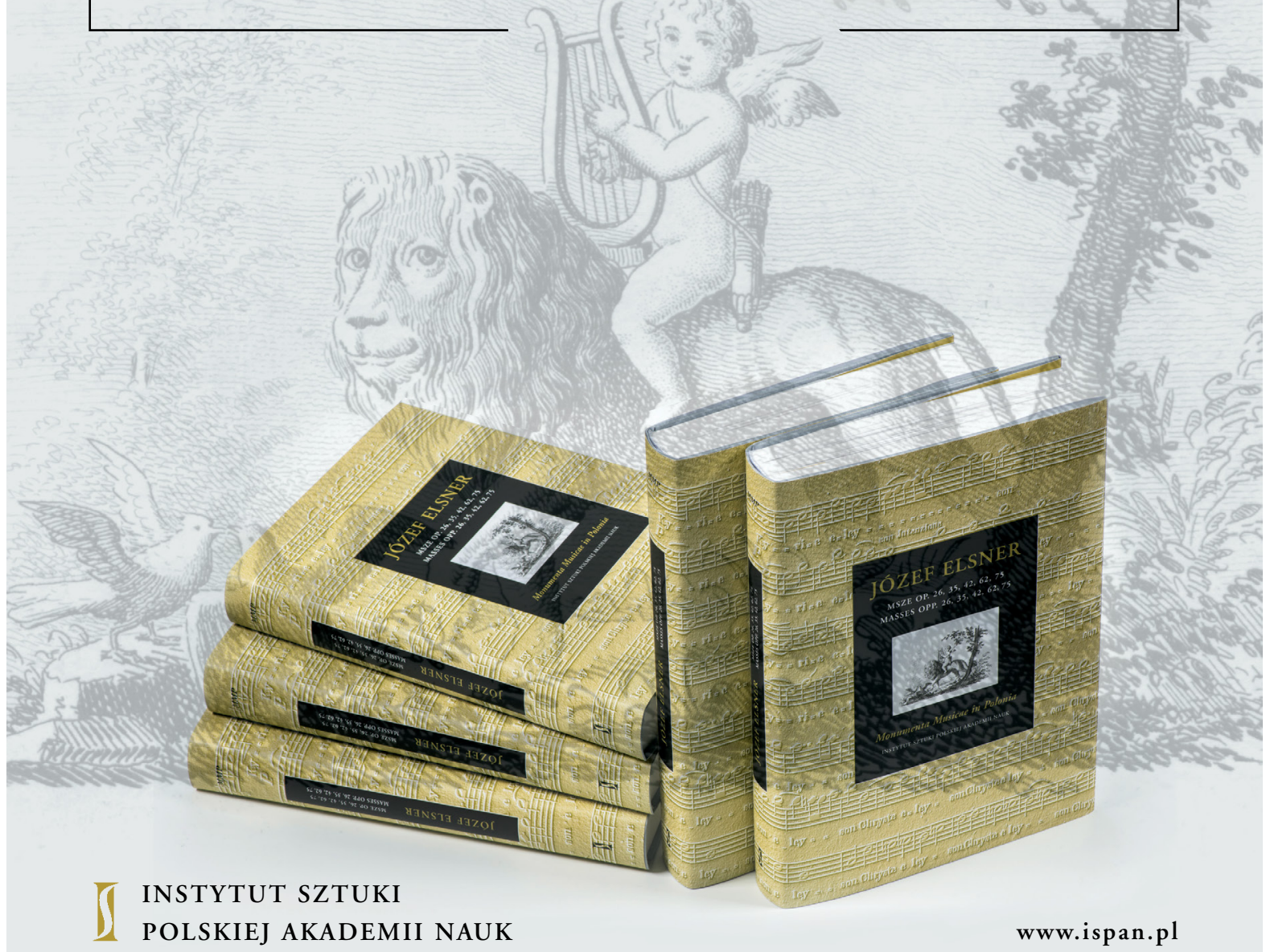

Seria - Series E

Opera Selecta 